POLITYKA ENERGETYCZNA - ENERGY POLICY JOURNAL

$2020 \downarrow$ Volume $23 \uparrow$ Issue $3 \nrightarrow 111-124$

DOI: $10.33223 / \mathrm{epj} / 127509$

Andrii Kytaiev ${ }^{1}$, Nina Chala ${ }^{2}$, Yehor Androsov ${ }^{3}$

\title{
Failures of energy policy in Ukraine in the context of energy security priorities
}

ABSTRACT: The issue of energy security was the subject of research in the 1970s when the oil crisis of 1973 significantly affected the economic stability of hundreds of companies and ordinary citizens in the United States and Western Europe. One of the first researchers of energy security was Mason Willrich who, considering the impact of energy on international politics, national security, the world economy, and the environment in the world, drew attention to the issues of "security of supply" and "security of demand" as fundamental to ensure energy security. The concept of "energy security" involves the comprehensive implementation of political, economic, environmental, technological, and social measures to strengthen the internal subjectivity of the state and limit opportunities for external influence. Subsequently, numerous researchers have expanded the understanding of energy security to environmental sustainability and energy efficiency). The presented scientific work is focused on the analysis of state management decisions for ensuring the energy security of

$\bowtie$ Corresponding Author: Andrii Kytaiev; e-mail: a.kytaiev@gmail.com

${ }^{1}$ Head of the Center for Energy Management, National University of "Kyiv-Mohyla Academy", aspirant of the Department of Marketing and Business Management, National University of "Kyiv-Mohyla Academy", Ukraine; ORCID iD: 0000-0001-5860-8690; e-mail: a.kytaiev@gmail.com

2 Faculty of Economy Sciences, National University of "Kyiv-Mohyla Academy", Ukraine; ORCID iD: 0000-00020356-9003; e-mail: n.chala@ukma.edu.ua

3 Student of masters program Energy Efficiency Management, Marketing and Business Management Department, National University of "Kyiv-Mohyla Academy”, Ukraine; ORCID iD: 0000-0002-7040-0291; e-mail: yegor.androsov@ ukma.edu.ua

2020. The Author(s). This is an open-access article distributed under the terms of the Creative Commons Attribution-ShareAlike International License (CC BY-SA 4.0, http://creativecommons.org/licenses/by-sa/4.0/), which permits use, distribution, and reproduction in any medium, provided that the Article is properly cited. 
Ukraine. The authors also trace vulnerabilities in various energy systems, including energy infrastructure, energy services, and renewable energy sources. The decline in energy demand due to the COVID-19 pandemic in Ukraine has created a dilemma: state support for renewable energy production (RES), which generates rising producer prices, or reduced energy intensity of GDP and stimulated production of cheap nuclear energy. A comprehensive scientific analysis of the solution to this dilemma is the purpose of the presented work.

KEYWORDS: renewable energy, electricity market, energy security, nuclear energy, coal energy

\section{Introduction}

The dependence of modern societies on a constant, reliable, and inexpensive supply of energy is the cause of many political problems and reactions, both domestically and internationally. For a long time, researchers have linked the assessment of the level of development of the country, economic growth with energy prices, and consumption (Ang et al. 2015). The question of the impact of energy policy on the country's development affects all the reports of the Club of Rome (Energoatom, n.d.; Meadows et al. 2006; Weizsäcker and Wijkman 2018). Attempts to ensure energy independence and avoid energy poverty significantly affect government decision -making, regardless of the political system and level of development of countries (Ministry of Energy of Ukraine 2017).

The issue of energy security was the subject of research in the 1970s when the oil crisis of 1973 significantly affected the economic stability of hundreds of companies and ordinary citizens in the United States and Western Europe. One of the first researchers of energy security was Mason Willrich (Parliament of Ukraine 2016), who, considering the impact of energy on international politics, national security, the world economy, and the environment in the world, drew attention to the issues of "security of supply" and "security of demand" as fundamental to ensure energy security (Willrich 1978). The concept of "energy security" involves the comprehensive implementation of political, economic, environmental, technological, and social measures to strengthen the internal subjectivity of the state and limit opportunities for external influence. Subsequently, numerous researchers have expanded the understanding of energy security to environmental sustainability and energy efficiency (Parliament of Ukraine 2020a). The study of the impact of supply diversification on energy availability has established the concept of security of supply as one of the main factors of the energy security system. The general conclusion of the analysis of modern scientific achievements in the field of energy security is the postulate that the role, place, competitiveness, and geopolitical potential of the country are largely determined by its energy and energy supply in the required amounts according to certain nomenclature, appropriate quality, and affordable price. At the same time, the role of state institutions and state bodies that protect the interests of society in shaping energy policy and achieving energy security priorities is crucial. 
The modern method for research in the field of energy security is an interdisciplinary approach to the problem which covers topics of climate change, globalization and future of fossil fuels use, energy sustainability and vulnerability of the energy system, energy efficiency, reduction of greenhouse gases emissions. Social aspects such as availability of energy services, transparency of energy projects, energy culture, and literacy are added to this. Energy security is now seen as an integral part of the country's overall security. The world scientific literature includes numerous works on energy security which can be grouped depending on the focus of research on the "logic of war", "logic of existence", "logic of general security". These different approaches in research generate a scientific discourse and form fundamentally different management decisions, regulations, and government priorities (Luttwak 2001).

The presented scientific work is focused on the analysis of state management decisions for ensuring the energy security of Ukraine. The authors also trace vulnerabilities in various energy systems, including energy infrastructure, energy services, and renewable energy sources. The decline in energy demand due to the COVID-19 pandemic in Ukraine has created a dilemma: state support for renewable energy production (RES), which generates rising producer prices, or reduced energy intensity of GDP and stimulated production of inexpensive nuclear energy. A comprehensive scientific analysis of the solution to this dilemma is the purpose of the presented work.

\section{Priorities of energy policy in Ukraine}

The country's energy policy is determined by the sequence of public management decisions that are made and implemented. In turn, managerial decision-making opportunities are limited by existing international obligations and the country's national interests. Regarding the international obligations undertaken by Ukraine by signing the UN Millennium Declaration, the Association Agreement between Ukraine, on one hand, and the European Union, the European Atomic Energy Community and their Member States, on the other hand, has to move to a model of sustainable development of the country (Parliament of Ukraine 2019). Ukraine joined the development of the Sustainable Development Goals, approved during the $70^{\text {th }}$ session of the UN General Assembly at the UN Summit on Sustainable Development in the final document "Transforming Our World: the 2030 Agenda for Sustainable Development". At the global level, 17 sustainable development goals have been approved (United Nations 2015). This is guiding the governments of all countries regardless of the level of economic development and political system. Among these 17 Objectives is Objective 7 to ensure access to modern energy sources. Progress in achieving these declarations is determined by the following indicators: expansion of infrastructure and modernization of the network to ensure a reliable and sustainable energy supply, diversification of primary energy supply, increase in the share of energy from renewable sources, increase energy efficiency (Parliament of Ukraine 2020a). Based on these indicators, decisions should be made on the implementation of energy policy. 
Establishing the Energy Community ratified by the Verkhovna Rada, the Treaty states the provision specifically and prohibits any discriminatory actions: "Nothing in this Agreement shall affect the right of a Party to determine the conditions of use of its energy resources and its choice between different energy sources and the overall structure of its energy supply" (State Agency for Energy Efficiency of Ukraine, n.d.). On February 1, 2011, Ukraine became a full member of the Energy Community, and in October 2012, through the Decision of the Council of Ministers of the Energy Community D/2012/04/MC-EnC, Ukraine undertook to implement laws, regulations, and administrative provisions necessary to comply with Directive 2009/28/EU of the European Parliament and of the Council of April 23, 2009, on the promotion of the use of energy from renewable sources (Decision of the Ministerial Council of The Energy Community 2012). Directive 2009/28/EU set binding national targets for renewable energy primarily to provide certain guarantees to investors and to encourage the development of new technologies and innovations in this field (Directive 2009/28/EC 2009).

Ukraine's energy strategy until 2035 provides for the development of the energy market, in particular: the creation of competitive markets for gas, electricity, heat, coal, oil and petroleum products, a transparent and non-discriminatory mechanism for tariff formation (Smil 2017). Balancing the interests of consumers, economic entities engaged in energy and utilities, and the state, energy security, European integration of electricity and natural gas markets of Ukraine provides the National Commission for State Regulation in the field of energy and utilities (NERC). NERC determines the rules for regulating the energy market in Ukraine, under development priorities. The filling of the wholesale market with financial resources and the behavior of market subjects depend on its decisions on tariff regulation: investing in RES, extending the service life of old power units, or building new ones; formation of local energy systems, new ones, and formation. Therefore, the decisions of the NERC should be based on ensuring the energy security of the country, in line with the Energy Strategy of Ukraine, and not to violate existing international agreements.

\section{Financial models of RES support in the EU countries and in Ukraine}

For the purpose of analysis of the management decisions of the NERC, authors examined the financial models of RES support used in other countries. As a rule, they are associated with financial incentives and quotas.

In particular (Yergin 2008):

$\checkmark$ Fixed preferential tariffs, or feed-in tariffs (FIT), which operate in more than 70 countries and have proven their effectiveness in the development of wind energy, especially in Germany, Spain and Denmark. Network operators receive a fixed fee for each kilowatt-hour of electri- 
city generated and supplied from RES. The tariff surcharge is compensated at the expense of the budget or the final consumer of electricity.

- Fixed preferential payments, or "environmental bonuses", are a fixed premium to the wholesale price of electricity, which, unlike a fixed tariff, is more difficult to predict due to the everchanging price in the wholesale electricity market.

- The fixed premium system is most widely represented in Spain. In the U.S., Canada, and other countries, tax breaks offer taxes for every kilowatt-hour produced.

Regarding RES quota systems, a system of tenders and a system of "green certificates" are used.

\ The system of tenders provides for a tender for the right to obtain the most economically advantageous contract for the construction and operation of RES facilities. This system has been used to develop wind energy in Ireland, France, the U.K., Denmark, and China (Yergin 2008).

The disadvantage of the system is that investors can offer an economically unreasonable low price to win the tender, and then they simply do not implement the project. For example, in the UK, a number of contracts has remained unfulfilled.

- System of trade in "green" certificates. According to this scheme, for each kWh produced on the basis of RES "green" certificates are issued, which can be sold on the free market. Proceeds from their sale are a surcharge to the base rate (Yergin 2008).

The system of "green" certificates usually operates in parallel with quotas for electricity production based on RES. To finance the additional costs associated with the production of electricity from RES and ensure the established volume of its production producers are required to purchase an appropriate number of "green" certificates from other producers of electricity from RES, covering a certain percentage or quota of total consumed/produced electricity (Yergin 2008).

Such a system is adopted in Great Britain, Sweden, Italy, and a number of US states. As producers/consumers want to buy such certificates as cheaply as possible a secondary market for certificates began to develop, in which electricity RES producers will compete with each other on the terms of sale of "green" certificates (Yergin 2008).

Compared to the tender system, trading in "green certificates" is more risky for the investor, as the trade is conducted on a daily basis and the price of "green certificates" fluctuates.

The main conclusions of the use of these mechanisms are as follows (Yergin 2008):

1) regardless of the chosen strategy the most important factor is a clear focus on promoting the development of new energy sources;

2) successfully developed (dynamic) system of preferential compensatory tariffs provides sustainable development of RES taking the lowest costs into account;

3) incentives strategies with low political risks set minimum requirements for profits for investors and, accordingly, reduce the cost of developing RES.

Ukraine uses fixed preferential tariffs, but the source of their implementation is the money of the state-regulated energy market. Table 1 shows a comparison of green tariffs in Ukraine and developed EU countries. 
TABLE 1 . The cost of electricity produced by RES in Ukraine and EU countries

TABELA 1. Koszt energii elektrycznej wytwarzanej z OZE na Ukrainie i w krajach UE

\begin{tabular}{|c|c|c|c|c|c|c|c|}
\hline Specification & $\begin{array}{c}\text { Ukraine }- \\
\text { Law } \\
\text { [EUR/kWh] }\end{array}$ & $\begin{array}{c}\text { Ukraine- } \\
\text { Memorandum } \\
{[\text { EUR/kWh] }}\end{array}$ & $\begin{array}{c}\text { Austria } \\
{[\text { EUR/kWh] }}\end{array}$ & $\begin{array}{c}\text { Greece } \\
\text { [EUR/kWh] }\end{array}$ & $\begin{array}{c}\text { Germany } \\
{[\text { EUR/kWh] }}\end{array}$ & $\begin{array}{c}\text { Switzerland } \\
{[\text { EUR/kWh] }}\end{array}$ & $\begin{array}{c}\text { Serbia } \\
\text { [EUR/kWh] }\end{array}$ \\
\hline $\begin{array}{c}\text { Solar Power } \\
\text { Plant }\end{array}$ & 0.16 & 0.134 & 0.077 & 0.09 & 0.16 & 0.11 & 0.09 \\
\hline $\begin{array}{c}\text { Wind Power } \\
\text { Plant }\end{array}$ & 0.102 & 0.095 & 0.082 & 0.16 & 0.105 & 0.114 & 0.092 \\
\hline Biofuels & 0.124 & 0.124 & 0.101 & 0.16 & 0.135 & 0.154 & 0.13 \\
\hline
\end{tabular}

Source: UkrEnergo 2018.

\section{State regulation of RES development in Ukraine}

The development of RES in Ukraine was to take place in accordance with the National Action Plan for the Development of RES until 2020, which was approved by the order of the Cabinet of Ministers of Ukraine №902-r of 01.10.2014 (UkrEnergo 2012).

The implementation of the Plan required coordinated actions of all government agencies and companies operating in the energy sector, such as follows:

$\checkmark$ Ministry of Energy and Coal Industry of Ukraine, which was to formulate and implement the energy policy taking the requirements of the "green" transition into account;

$\checkmark$ NERC, which was to form and implement the tariff policy in the field of energy;

$\checkmark$ The State Agency for Energy Efficiency, which by order of the Cabinet of Ministers of Ukraine was to administer the actions of market participants to implement the National Action Plan for the development of RES until 2020;

$\downarrow \mathrm{SE}$ UkrEnergo, which was to provide operational activities for the issuance of technical conditions (TC) to new companies to join the general power grid in accordance with the approved National Action Plan for the development of RES until 2020 (Parliament of Ukraine 2014).

Insufficiently controlled processes in the field of RES development allowed the state operator of electricity transmission systems - UkrEnergo - as of the end of 2019 to issue TC (technical conditions) for connection to SPP (solar power plant) networks with an installed capacity of $12 \mathrm{GW}$, which is 5.4 times higher than provided by the Plan (Table 2). The issuance of TC is the basis for the company to obtain a loan from its owner in Ukrainian and international banks. The cost of $1 \mathrm{~kW}$ of installed SPP capacity on the market is EUR 600-700. The total cost of SPP construction projects increased to EUR 7.2 billion, of which up to $85 \%$ could be covered by Ukrainian and international banks. 
TABLE 2. Status of implementation of the National Action Plan for RES Development until 2020 with a forecast of indicators for 2020

Tabela 2. Stan realizacji Krajowego Planu Działań na Rzecz Rozwoju OZE do 2020 roku wraz z prognozą wskaźników na 2020 rok

\begin{tabular}{|l|c|c|c|c|}
\hline \multicolumn{1}{|c|}{ Specification } & $\begin{array}{c}\text { Installed generation } \\
\text { capacity with RES } \\
\text { (SPP, WPP (wind power } \\
\text { plant, biofuel) }\end{array}$ & $\begin{array}{c}\text { Installed generation } \\
\text { capacity with } \\
\text { RES - SPP }\end{array}$ & $\begin{array}{c}\text { Installed generation } \\
\text { capacity with } \\
\text { RES - WPP }\end{array}$ & $\begin{array}{c}\text { Installed } \\
\text { generation capacity } \\
\text { with RES - biofuel }\end{array}$ \\
\hline Plan for 2020 & $5580 \mathrm{MW}$ & $2300 \mathrm{MW}$ & $2280 \mathrm{MW}$ & $950 \mathrm{MW}$ \\
\hline Fact of 2020 & $6871 \mathrm{MW}$ & $5614 \mathrm{MW}$ & $1075 \mathrm{MW}$ & $182 \mathrm{MW}$ \\
\hline Discrepancy & $+25 \%$ & $+150 \%$ & $-50 \%$ & $-80 \%$ \\
\hline $\begin{array}{l}\text { Planed delivery to the } \\
\text { network - 2020, kW }\end{array}$ & $11.8 \mathrm{TW}$ & $2.76 \mathrm{TW}$ & $5.81 \mathrm{TW}$ & $3.23 \mathrm{TW}$ \\
\hline $\begin{array}{l}\text { Actual delivery to the } \\
\text { network, kW }\end{array}$ & $9.74 \mathrm{TW}$ & $6.74 \mathrm{TW}$ & $2.74 \mathrm{TW}$ & $618.8 \mathrm{MW}$ \\
\hline $\begin{array}{l}\text { Financial liabilities for } \\
\text { settlements with suppliers, } \\
\text { UAH }\end{array}$ & $39,905,159,500$ & $30,989,280,000$ & $8,086,687,500$ & $829,192,000$ \\
\hline $\begin{array}{l}\text { Deviation of delivery to } \\
\text { a network, kW }\end{array}$ & $-1.7 \mathrm{TW}$ & $+3.97 \mathrm{TW}$ & $-3.07 \mathrm{TW}$ & $-2.61 \mathrm{TW}$ \\
\hline $\begin{array}{l}\text { Additional financial } \\
\text { burden per year, UAH }\end{array}$ & $+5,729,659,500$ & $+18,293,280,000$ & $-9,064,612,500$ & $-3,499,008,000$ \\
\hline
\end{tabular}

Source: UkrEnergo 2018.

As a result of management mistakes made during the implementation of the RES Development Plan, an imbalance arose, which on the one hand did not allow to achieve the planned indicators of RES development (50\% of the planned) and biofuel power plants ( $20 \%$ of the planned), but significantly exceeded construction limits of SPP (exceeding $+150 \%$ ) with the highest tariff for electricity supply to public networks. In 2019, due to imperfect management generation facilities from alternative sources with a total capacity of $6,871 \mathrm{GW}$ were put into operation (exceeding the Plan was $+25 \%$ ). According to the authors, preliminary estimates, in 2020, the generation of electricity from RES will amount to $9.7 \mathrm{TWh}$ of electricity, for which its producers will receive up to UAH 39.9 billion. (In comparison - SE EnergoAtom indicators for $83 \mathrm{TWh}$ are UAH 45.65 billion).

As a result of discriminatory regulation, EnergoAtom supplied $53.9 \%$ of the total volume of the wholesale market with the electricity of its own production -83 billion $\mathrm{kWh}(2019)$ but received less than $28 \%$ of the total balance of consumer payments for electricity (UAH 45.65 billion - 2019). Discriminatory actions of the state regulator created a commodity reserve in the amount of up to $25 \%$ of the amount of electricity supplied to the wholesale market, which through sales to end consumers was transformed into a financial resource in the amount of UAH 50 billion per year or about EUR 1.666 billion, which was transferred to the management of the state operator - SE Guaranteed Buyer (before - SE Energy Market). Meanwhile, the state regu- 
lator in Ukraine did not change the discriminatory model of filling the wholesale energy market with money at the expense of EnergoAtom but focused on the initiation of "green" tariffs, which put in a privileged position new market participants e.g., investors in RES and energy based on hydrocarbon generation. As a result, the discriminatory tariff for the purchase of electricity produced by EnergoAtom amounted to UAH 0.55 per $1 \mathrm{kWh}$, which was less than $50 \%$ of the average wholesale market price, UAH 1.11 per $1 \mathrm{kWh}$, and the tariff for other market participants was significantly higher: for solar power plants (SPP) $1 \mathrm{kWh}$ is UAH 4.6, for wind power plants (WPP) - UAH 2.95, for biomass power plants - UAH 3.72, for DTEK coal-fired power plants UAH 1.77 (average selling price of electricity of TPP Group) (NERC n.d.).

In line with the authors, the state regulator's discriminatory tariff policy resulted in loss by the state-owned EnergoAtom more than USD 20 billion in gross profit over the past 10 years, which can be seen as Ukraine's investment contribution to energy development.

In accordance with the priorities of energy security, the following funds should be spent on the implementation of long-term priorities of the energy policy of Ukraine, which should address pressing issues in the context of energy security:

$\checkmark$ reducing dependence on energy imports;

$\checkmark$ reducing the energy intensity of the industry;

$\downarrow$ raising environmental standards and reducing $\mathrm{CO}_{2}$ emissions;

$\downarrow$ development of the domestic energy market;

$\downarrow$ avoidance of critical external financial and resource dependence;

$\checkmark$ attracting investments to realize its own energy potential;

$\checkmark$ initiation of research and scientific developments in the energy sector.

Meanwhile, the recipients of these funds were private companies that used them at their own discretion for their own purposes.

\section{Economic and political consequences of energy policy failures in Ukraine and in the world}

Failures in the implementation of Ukraine's energy policy have created conditions for significant economic losses of the state due to the uncontrolled growth of state-guaranteed external and internal liabilities resulting in the need to increase electricity prices for consumers and bring to artificial default state companies e.g., EnergoAtom, UkrEnergo, and SE Guaranteed Buyer (UA News 2019; EXPRO Consulting 2020).

It can be seen from the above calculations (Table 2) that the energy market costs for the purchase of solar energy generated above the Plan will amount to an additional UAH 30.9 billion, of which at least UAH 5.7 billion is more than the total Plan.

According to available information, investors in Ukraine have received technical conditions for the construction of their own SES, the capacity of which is 10,000 MW higher than the ap- 
proved RES development plan. Technical conditions for the Investor are the basis for attracting co-financing for their projects based on their price, which is EUR 750,000 per $1 \mathrm{MW}$ of installed capacity.

Given these circumstances, the amount of potential claims of banks/investors to Ukraine excluding court costs and compensation for non-pecuniary damage may amount to EUR 7.2 billion (4.7\% of Ukraine's annual GDP in 2019), which is a critical burden on Ukraine's economy (Mind ua 2019; Eds-development 2020; Worldbank 2019).

History has examples where the implementation of threats to energy security in combination with other factors has led to the destruction of state entities. Thus, the consequences of the 1973 oil crisis together with decisive impact on international politics and the further development of the world economy played a decisive role in the collapse of the Soviet Union. Due to a number of managerial mistakes, the USSR lost its primary benefits as a result of the 1973 oil crisis and was unable to use the financial resources effectively to harmonize its own economy, leading to a systemic crisis and the country's collapse. The refusal by OPEC countries to supply oil to Western countries (1973) created conditions for the Soviet Union's energy expansion into Europe. Long-term agreements in the energy sector were signed, which led to the creation of an export infrastructure e.g., a network of oil and gas pipelines. The volume of foreign exchange earnings from energy exports to the USSR has grown significantly: if in 1970 the foreign exchange earnings of the USSR in this area amounted to USD 1.05 billion, in 1975 it amounted to USD 3.72 billion, and in 1980 brought to the treasury already USD 15.74 billion. Profits from energy sales reduced the relevance of the final stage of Kosygin's (prime minister) economic reform, which was supposed to solve the growing problems in agriculture in the USSR by freeing wholesale purchase prices from regulation and replacing the centralized State Supply with a market mechanism of wholesale trade.

At the same time, the lack of domestic sources of income and incentives for food production led to a critical dependence of the USSR on exports of energy and raw materials, the share of which in 1985 was $54 \%$ in the structure of Soviet exports. It is the decline in energy revenues that has become a decisive destabilizing factor which has widened budget gaps and initiated a food crisis. Tensions in the budget were covered by inflation, which later, together with growing ideological and national conflicts, led to social explosions, the food crisis, and the collapse of the USSR in 1991.

A positive example of overcoming the energy crisis is the example of the United States. In 1973, the oil crisis of 1973 hit the automotive industry, where the place of American cars with large engine volumes was replaced by economic cars from Japan. Rising logistics costs have significantly increased prices for almost all goods and created social tension. Thrifty energy consumption has become a necessity for ordinary Americans. The U.S. has assessed the threats that have arisen and has begun to systematically address energy security. Several think tanks were established and developed with state support. Their task was to ensure the global monitoring of processes in world energy, as well as their forecast in the medium and long term. Research and breakthrough energy and energy-saving technologies have been developed and supported by the state. The U.S. initiated the creation of internal compensators to neutralize external negative 
factors. One such compensator was the creation of the world's largest Strategic Oil Reserve in 1975, which accumulated the available state oil reserve of 695.6 million barrels (2013).

Therefore, different approaches to the implementation of energy policy, assessment, and organization of countering threats to energy security have the opposite impact on the stability of countries and their role in the world.

\section{Conclusions}

The emergence of the Energy Crisis in Ukraine is associated with failures in the implementation of the energy policy in Ukraine and unprofessional actions in the public administration system.

Discriminatory actions of the state regulator NERC in the development and implementation of the tariff policy against one of the market participants in particular SE EnergoAtom, which is a violation of Article 7 of the Charter of the Energy Community led to the loss of state company over the past 10 years reaching about EUR 20 billion, which have not become a resource for the development of Ukraine's energy system in the context of energy security priorities.

Failures in the administration of the RES Development Plan until 2020 by the State Agency for Energy Efficiency have led to a significant imbalance in the development of RES generation, which manifested itself in exceeding the quota for the construction of SPP by $150 \%$ and failure to meet the targets for wind farms (only $50 \%$ of Plan), on biofuels is only $20 \%$ of the Plan.

The imbalance that arose during the implementation of the RES Development Plan until 2020 also has severe financial consequences, including an increase in the financial burden on the wholesale market in 2020 by UAH 5.7 billion in absolute terms for all types of RES and UAH 18.3 billion for an indicator of the unplanned generation of SPP.

The uncontrolled issuance of technical conditions for the construction of unscheduled SPP by the state company, energy network operator UkrEnergo, has led to the creation of conditions for obtaining loans and attracting investments for the construction of SPP with an installed capacity of $12 \mathrm{GW}$ worth up to EUR 7.2 billion, which exceeds the Plan 5.2 times.

The construction of the SPP with a total capacity of $12 \mathrm{GW}$ in the shortest possible time will lead to an annual generation of solar electricity in the amount of $14.4 \mathrm{TWh}$ with the emergence of state-guaranteed obligations to purchase it in the amount of UAH 66.24 billion per year. Without a significant reduction in the "green" tariff for SPP, such actions will lead to a sharp rise in electricity prices for consumers, the loss of high-tech jobs in the industry, and create unfavorable conditions for industrial production in Ukraine.

Balancing the development of the energy system of Ukraine should take the priorities of energy security into account, which requires the planned decommissioning of energy facilities, the service life of which has ended taking modern environmental requirements for generation facilities into account. 
The personnel positions of state bodies responsible for the administration of energy development measures, as well as law enforcement bodies which monitor compliance with energy security priorities and counter risks in this area, need to be significantly strengthened.

\section{References}

Ang et al. 2015 - Ang, B., Choong, W. and NG, T. 2015. Energy security: Definitions, dimensions and indexes. Renewable and Sustainable Energy Reviews Vol. 42., pp. 47-89.

Decision of the Ministerial Council of the Energy Community 2012. [Online] https://energy-community.org/dam/jcr:7109a56a-7cf6-4cc8-a971-2450594ffe6c/Decision_2012_03_MC_OIL.pdf [Accessed: 2020-08-05].

Directive 2009/28/EC of the European Parliament and of the Council of 23 April 2009. [Online] https://eur-lex.europa.eu/legal-content/EN/TXT/PDF/?uri=CELEX:32009L0028\&from=EN [Accessed: 2020$-07-03]$.

Eds-development (2020). How much does it cost to build a SES per 1 MW. Income and payback period (Skilky koshtuie pobuduvaty SES na 1 MVt. Dokhid ta terminy okupnosti). [Online] https:// www.google.com/url?sa=D\&q=https://eds-development.com/zemelni-dilyanki-pid-budivnictvo-1-mvt-ses-chomu-v-2020-r-ce-trend-ukrainskogo-rinku-vidnovljuvanoi-energetiki\&ust=1599406200000000\&usg=A-OvVaw3LupG8u63UmtvHBIKl-jkA\&hl=ru\&source=gmail [Accessed; 2020-08-02] (in Ukrainian).

Energoatom. n.d. Energoatom | Home page (Enerhoatom | Holovna storinka). [Online] http://www.energoatom.com.ua/ua/ [Accessed: 2020-07-31] (in Ukrainian).

EXPRO Consulting 2020. NERC extended for suppliers up to 7 days the period of payment of bills to Ukrenergo before the acquisition of pre-default - EXPRO Consulting (NKREKP rozshyryla dlia postachalnykiv do 7 dniv period oplaty rakhunkiv pered «Ukrenerho» do nabuttia pereddefoltu - EXPRO Consulting). [Online] https://expro.com.ua/novini/nkrekp-rozshirila-dlya-postachalnikv-do-7-dnv-perodoplati-rahunkv-pered-ukrenergo-do-nabuttya-pereddefoltu [Accessed: 2020-08-05] (in Ukrainian).

LutTwaK, E. 2001. Strategy: the logic of war and peace. Cambridge, Mass.; London: Belknap Press Of Harvard University Press.

Meadows et al. 2006 - Meadows, D., Randers, J. and Meadows D. 2006. Limits to Growth. The 30-Year Update. Earthscan: London.

Mind ua. 2019. Law on "green" auctions: how to prevent the collapse of the electricity market (Zakon pro «zeleni» auktsiony: yak zapobihty obvalu rynku elektroenerhii). [Online] https://mind.ua/publications/20196748-zakon-pro-zeleni-aukcioni-yak-zapobigti-obvalu-rinku- [Accessed: 2020-08-01] (in Ukrainian).

Ministry of Energy of Ukraine 2017. Energy Strategy of Ukraine for the Period until 2035 "Security, Energy Efficiency, Competitiveness" (Enerhetychna Stratehiia Ukrainy na Period do 2035 roku «Bezpeka, Enerhoefektyvnist, Konkurentospromozhnist»). [Online] http://mpe.kmu.gov.ua/minugol/doccatalog/ document?id=245239554 [Accessed: 2020-08-01] (in Ukrainian).

NERC (n.d.). National Commission for State Regulation of Energy and Utilities (Natsionalna komisiia, shcho zdiisniuie derzhavne rehuliuvannia u sferakh enerhetyky ta komunalnykh posluh). [Online] http:// www.nerc.gov.ua/ [Accessed: 2020-08-01] (in Ukrainian).

Parliament of Ukraine 2014. About the National Renewable Energy Action Plan for the period up to 2020 (Pro Natsionalnyi plan dii z vidnovliuvanoi enerhetyky na period do 2020 roku). [Online] https://zakon. rada.gov.ua/laws/show/902-2014-\%D1\%80\#Text [Accessed: 2020-08-05] (in Ukrainian). 
Parliament of Ukraine 2016. About the National Commission for State Regulation of Energy and Utilities (Pro Natsionalnu komisiiu, shcho zdiisniuie derzhavne rehuliuvannia u sferakh enerhetyky ta komunalnykh posluh). [Online] https://zakon.rada.gov.ua/laws/show/1540-19\#Text [Accessed: 2020-07-31] (in Ukrainian).

Parliament of Ukraine 2019. About the Goals of sustainable development of Ukraine for the period up to 2030 (Pro Zili stalogo rozvytku Ukrainy na period do 2030 roku). [Online] https://zakon.rada.gov.ua/ laws/show/722/2019\#Text [Accessed: 2020-08-05] (in Ukrainian).

Parliament of Ukraine 2020a. Legislation of Ukraine (Zakonodavstvo Ukrainy). [Online] https://zakon. rada.gov.ua/laws/show/902-2014- [Accessed: 2020-07-31] (in Ukrainian).

Parliament of Ukraine 2020b. Treaty establishing the Energy Community (Ofitsiinyi vebportal parlamentu Ukrainy. (2020). Dohovir pro zasnuvannia Enerhetychnoho Spivtovarystva). [Online] https://zakon. rada.gov.ua/laws/show/994_926\#Text [Accessed: 2020-07-31] (in Ukrainian).

State Agency for Energy Efficiency of Ukraine (n.d.). Welcome to the State Agency for Energy Efficiency of Ukraine | State Agency for Energy Efficiency of Ukraine (Welcome to Derzhenerhoefektyvnosti Ukrainy | Derzhenerhoefektyvnosti Ukrainy). [Online] https://saee.gov.ua/ [Accessed: 2020-07-31] (in Ukrainian).

SmIL, V. 2017. Energy and Civilization: A History. [Online] Google Books. MIT Press. [Online] https:// books.google.com.ua/books?id=58MjDwAAQBAJ\&pg=PA552\&dq=Smil+V.+Energy+and + civilization:+a+history+/+Vaclav+Smil.+-+Cambridge:+The+MIT+Press [Accessed: 2020-07-31].

sustainabledevelopment.un.org. (n.d.). Ukraine: Sustainable Development Knowledge Platform. [Online] https://sustainabledevelopment.un.org/index.php?page=view\&type $=30022 \& \mathrm{nr}=1699 \& \mathrm{me}-$ $\mathrm{nu}=3170 \& \mathrm{fbclid}=\mathrm{IwAR} 3 \times \mathrm{x}$ xt53hm-KfMznWUHtVaBKjPDJeQfQamx5KipPYq0CqBb41 srod1o4t0 [Accessed: 2020-07-31].

UA News 2019. Hundreds of companies are threatened with exclusion from the energy market due to default (Sotniam kompanii zahrozhuie vykliuchennia z enerhorynku cherez defoltu). [Online] https:// ua.news/ru/sotnyam-kompanij-zagrozhuye-vyklyuchennya-z-energorynku-cherez- [Accessed: 202008-05] (in Ukrainian).

UkrEnergo 2012. Foreign practice of stimulating the development of renewable energy sources and their connection to the power grid (Zarubizhna praktyka stymulyuvannya rozvytku ponovlyuvanykh dzherel enerhiyi ta yikh pryyednannya do elektromerezh enerhosystem). [Online] https://ua.energy/wp-content/ uploads/2018/01/5.-Praktyka_stymul_rozvyt_PDE.pdf [Accessed: 2020-07-31] (in Ukrainian).

UkrEnergo 2018. Analysis of electricity tariffs and pricing in the EU and OECD countries. Incentive tariff systems (Analiz taryfo- ta tsinoutvorennia na elektroenerhiiu u krainakh YeS ta OESR. Systemy stymuliuiuchoho taryfoutvorennia). [Online] https://ua.energy/wp-content/uploads/2018/10/3.-Taryfo_tsinoutv_elektroen.pdf [Accessed: 2020-08-16] (in Ukrainian).

United Nations (2015). \#Envision2030: 17 goals to transform the world for persons with disabilities $\mid$ United Nations Enable. [Online] Un.org. https://www.un.org/development/desa/disabilities/envision2030. html.

Weizsäcker, E. and Wijkman, A. 2018. Come On! Capitalism, Short-termism, Population and the Destruction of the Planet. A Report to the Club of Rome. Springer Science + Business Media LLC.

WiLlrich, M. 1978. Energy \& World Politics. [Online] Google Books. Simon and Schuster. [Online] https://books.google.com.ua/books?id=ckOF8GbGsDQC\&hl=uk\&source=gbs_navlinks_s [Accessed: 2020-07-31].

Worldbank 2019. GDP (current US\$) - Ukraine | Data. [Online] https://data.worldbank.org/indicator/ NY.GDP.MKTP.CD?locations=UA [Accessed: 2020-07-31].

Yergin, D. 2008. The Prize: The Epic Quest for Oil, Money \& Power. Free Press, New York, Reissue edition. 


\title{
Niepowodzenia polityki energetycznej na Ukrainie w kontekście priorytetów bezpieczeństwa energetycznego
}

\author{
Streszczenie
}

Zagadnienie bezpieczeństwa energetycznego było przedmiotem wielu badań w latach 70 . XX w., kiedy kryzys naftowy w 1973 r. znacząco wpłynął na stabilność ekonomiczną setek firm i zwykłych obywateli w Stanach Zjednoczonych i Europie Zachodniej. Jednym z pierwszych był Mason Willrich, który badając wpływ energii na politykę międzynarodową, bezpieczeństwo narodowe, gospodarkę światową i środowisko, zwrócił uwagę na kwestie „bezpieczeństwa dostaw” i „bezpieczeństwa dostępu do energii” jako fundamentalne dla zapewnienia bezpieczeństwa energetycznego.

Pojęcie „bezpieczeństwa energetycznego” zakłada kompleksową realizację działań politycznych, ekonomicznych, środowiskowych, technologicznych i społecznych, mających na celu wzmocnienie wewnętrznej podmiotowości państwa i ograniczenie możliwości wpływów zewnętrznych. Pojęcie bezpieczeństwa energetycznego zostało później rozszerzone o zagadnienia zrównoważenia środowiska i efektywności energetycznej.

Prezentowana praca koncentruje się na analizie decyzji zarządczych państwa dla zapewnienia bezpieczeństwa energetycznego Ukrainy. Autorzy identyfikują również słabe punkty w różnych systemach energetycznych, w tym w infrastrukturze energetycznej, usługach energetycznych i odnawialnych źródłach energii. Spadek zapotrzebowania na energię w wyniku pandemii COVID-19 na Ukrainie spowodował powstanie dylematu: czy państwo ma wspierać produkcję energii odnawialnej (OZE), co generuje rosnące ceny producentów, czy też zmniejszenie energochłonności PKB i stymulowanie produkcji taniej energii jądrowej.

Celem prezentowanej pracy jest wszechstronna analiza zmierzająca do rozwiązania tego dylematu.

SŁOWA KLUCZOWE: energia odnawialna, rynek energii elektrycznej, bezpieczeństwo energetyczne, energetyka jądrowa, energetyka węglowa 
